\title{
PeutzJeghers syndrome: A case report and literature review
}

\author{
Lakhey $\mathrm{A}^{1}$, Shakya $\mathrm{H}^{2}$ \\ ${ }^{\prime}$ Department of Pathology, Kist medical college, Lalitpur, Nepal \\ ${ }^{2}$ Department of Pediatrics, Kist medical college, Lalitpur, Nepal
}

\section{Keywords: \\ Mucocutaenous; \\ Pigmentation; \\ Gastrointestinal polyps; \\ Hamartoma.}

\begin{abstract}
Peutz-Jeghers Syndrome is an autosomal dominant inheritedhamartomatous polyp. We present a case of a 5-year-old young boywith a history of per rectal bleeding and mass protruding out of the anus. Physical examination revealed presence of mucocutaneous pigmented lesions over the tongue, and few hamartomatous polyps protruding out of the rectum suggesting Peutz-Jeghers syndrome. The presence in early infancy of small, well-demarcated and dark-brown to blue-black lentigines on the lips, buccal mucosa and perioral skin, should alert the clinician to Peutz-Jeghers Syndrome.
\end{abstract}

\section{INTRODUCTION}

PeutzJeghers Syndrome (PJS) is an inherited autosomal dominant disorder distinguished by hamartomatous polyps in the gastrointestinal tract and mucocutaneous lesions. Inheritence is autosomal dominant with a pleotrophic gene. Inactivation of this gene by germline mutations or loss of normal allele can result in hamartomatous polyps.

Prevalance of PJS is estimated from 1 in 8,300 to 1 in $280,000 \cdot{ }^{1-7}$ Well documented data on the incidence are not available. $^{7}$ It is accepted to be a precancerous syndrome. The polyps can cause anaemia and intestinal obstruction and intussusception. ${ }^{8}$ Those polyps are present from chilhood. ${ }^{9}$ The relative risk of dying from a gastrointestinal

\section{Correspondence:}

Dr. AshishLakhey MD

Kist medical college and hospital

Gwarko, Lalitpur, Nepal

Phone: +977-9846219215,E-mail: aashishlakhey@hotmail.com cancer is 13 fold elevated. ${ }^{10}$ Melanotic spots are the earliest manifestation of PJS, typically appearing in the first year of life. ${ }^{9}$ Extra-intestinal tumors associated with Peutz-Jeghers syndrome include ovarian, uterine cervix, testicular, breast, thyroid, bile duct, pancreas and gall bladder. ${ }^{11}$

\section{CASE REPORT}

A 5-year-old boy came to the ER with history of bleeding per rectum. Examinations showed a protruding rectal mass. Pigmented lesions were seen on the buccal mucosa and lower lip (fig.1). Mother noted pigmented spots when he was 5 years old. No family history of PJS or any other polyposis syndrome could be verified and both parents are free of symptoms. The mass was resected and sent for histopatholgical evaluation. Grossly the mass measured $6 \times 5 \times 4 \mathrm{~cm}$. The mass was soft and reddish to brownish with several adhered polyps (fig.2). Histologically, the polyps 


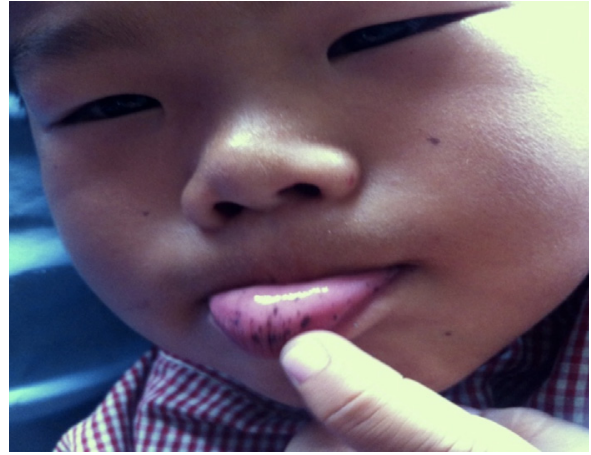

Figure 1: Mucocutaneous pigmentation in the lower lip.

exhibited arborization of muscularis mucosae covered with normal villiand was defined as a hamartoma, thus confirming theclinical diagnosis of PeutzJeghers Syndrome (fig. 3).

\section{DISCUSSION}

The first clear cut association of melanin pigmentation of the lips and buccal mucosa with intestinal polyposis was reported by Peutz in 1921. American physician Jegher published 10 additional cases in $1944 .{ }^{12}$

The World Health Organisation clinico-pathological criteria for diagnosing this rare disorder are:

1. Three or more polyps, which show histological features consistent with PJS.

2. A family history of PJS with any number of PJPs.

3. A family history of PJS with characteristic mucocutaneous pigmentation.

4. Characteristic mucocutaneous pigmentation with any number of PJPs. ${ }^{12}$

The characteristic pigmentation is present in more than $90 \%$ of the PJS cases. The pigmented macule may be present at birth but usually develop in early childhood, and even may develop later in life occasionally. Round, oval or irregular patches of brown or almost black pigmentation 1-5 mm in diameter are most commonly found around the mouth, nose, lower lip, buccal mucosa, hands and feet. ${ }^{9}$

The Peutz-Jeghers polyp is a unique hamartomatous lesion characterized by glandular epithelium that covers an arborizing framework of well-developed smooth muscle that is continuous with the muscularis mucosae. These polyps are usually multiple and their distinctive appearance, in association with extra-intestinal manifestations, makes Peutz-Jeghers syndrome easily identifiable. ${ }^{9}$

The most common location for polyps is the small bowel

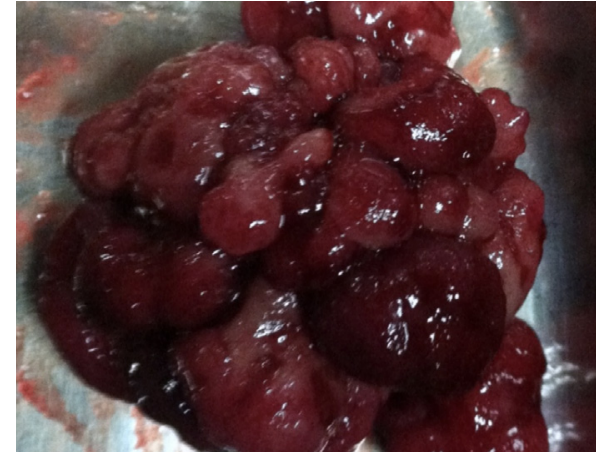

Figure 2: Multiple polyps of different sizes and shapes seen

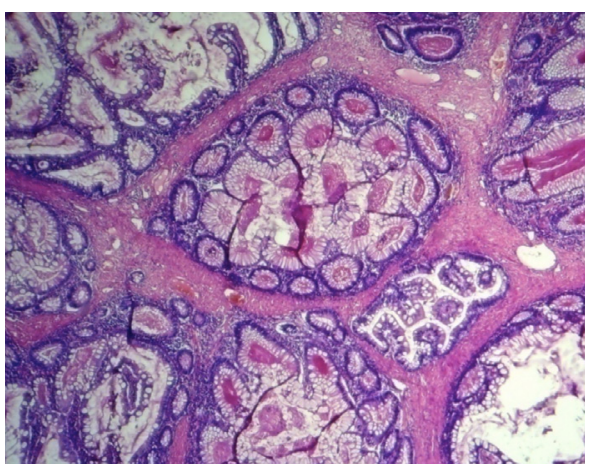

Figure 3: Microscopic section of a polyp showing arborizing muscular framework (HE stain, X 400).

(64\%), although involvement of the colon (53\%) stomach $(49 \%)$ and rectum (32\%) is also described. Usually there are fewer than 20 polyps present in each case, varying in size from several millimeters to more than $5 \mathrm{~cm}$ diameter. ${ }^{9}$

Patients are diagnosed usually in the second or third decade of life and common presentations include abdominal pain, rectal bleeding, anemia, small intestinal intussusception, bowel obstruction, and rectal prolapse of polyps. ${ }^{13}$ Abdominal symptoms tend to occur early in life, with more than $50 \%$ symptomatic patients before the age of $20 .{ }^{9,14}$

Although it has been found that there is a high cancer risk in PJS patients according to John Hopkin's hospital polyposis registry 6,no cancer was found in ourpatient's polyps.

Over the years, the standard therapy for Peutz-Jeghers syndrome has been laparotomy and bowel resection to remove symptomatic gastrointestinal polyps that cause persistent or recurrent intussusceptions. However, some patients require multiple surgical resections, which canlead to short gut syndrome. Because of this, it has been recommended that endoscopy be performed to remove all polyps. During each laparotomy, the small bowel should be examined by means of intraoperative enteroscopy. Nowadays, double balloonenteroscopy in combination with capsule enteroscopy are the gold standard for the diagnosis 
and treatment of the small bowel hamartomatous polyps. ${ }^{1}$

\section{CONCLUSION}

Peutz Jegher should be suspected in a child who presents with mucocutaneous pigmentation with gastrointestinal polyps. These patients should be regularly and closely monitored because of the risk of cancer and to reduce other morbidities.

\section{REFERENCES}

1. Kopacova M, Tacheci I, Rejchrt S, Bure J. Peutz-Jeghers syndrome: Diagnostic and therapeutic approach. World J Gastroenterol 2009; 15:5397-5408. Crossref

2. Miyaki M. Peutz-Jeghers syndrome. Nippon Rinsho 2000;58:1400-4. PMid:10921312

3. Choi HS, Park YJ, Youk EG et al. Clinical characteristics of PeutzJeghers syndrome in Korean polyposis patients. Int J Colorectal Dis 2000;15:35-8. Crossref

4. Westerman AM, Entius MM, de Baar E, et al. Peutz-Jeghers syndrome: 78-year follow-up of the original family. Lancet 1999;353:1211-5. Crossref

5. Choi HS, Park YJ, Park JG. Peutz-Jeghers syndrome: a new understanding. J Korean Med Sci 1999;14: 2-7. Crossref

6. Itzkowitz SH, Kim YS. Colonic polyps and polyposis syndromes. Feldman M, Scharschimidt BF, Sleisenger MH Sleisenger\&Fordtran's Gastrointestinal and Liver Disease. 6th Edition. Philadelphia, WB Saunders, 1998.pp113.
7. Aaltonen LA, Jarvilen H, Gruder SB, Billaud M, Jass JR. PeutzJeghers Syndrome. In: Hamilton SR and Aaltonen LA, editors. World Health Organization Classification of Tumours.Pathology and Genetics of Tumours of the Digestive System.Lyon, France: IARC Press; 2000. pp.74-6.

8. Mozaffar M,Sobhieh MR, Hasani M, Fallah M. Puetz-Jeghers syndrome without mucocutaneous pigmentation: a case report GastroenterolHepstol Bed Bencha 2012;5:169-73.

9. Georgescu E. F.,Stansescu L, SimionescuC,GeorgescuI,Inoescu R, Florescu G. Peutz-Jeghers Syndrome: Case report and literature review. Romanian Journal of Morphology and Embryology 2008;49:241-5. PMid:18516333

10. Saranrittichai S.Peutz-Jeghers Syndrome and Colon Cancer in a 10-Year-Old Girl: Implications for When and How to Start Screening? Asian Pacific Journal of Cancer Prevention 2008; 9:15961. PMid: 18439097

11. Almoutaz A El Tayeb, Naglaa H. Ibrahim, Azza A. ElTayeb, AE.Essa. Peutz-Jeghers Syndrome in Children and Adolescents. Annals of Pediatric Surgery 2008;4:37-4.

12. Girvin S, Glancy M, Dunlop M. Peutz-Jeghers syndrome: a case report and discussion of surveillance recommendations. Eur J Radiol Extra 2007;62:81-4. Crossref

13. Mcgarrity T.J., Amos C.,Peutz-Jeghers Syndrome: cliicopathology and molecular alterations, Cell Mol Life Sci 2006;63:2135-44. Crossref

14. Tovar JA, Eizaguirre AA, Jimenez J. Peutz-Jegher syndrome in children: report of two cases and review of literature. J PediatrSurg 1983;1:18. 